\title{
USE OF THE METHOD OF NET PRESENT VALUE IN BANKRUPTCY PROCEEDINGS OF INDUSTRIAL ENTERPRISES VYUŽITÍ METODY ČISTÁ SOUČASNÁ HODNOTA V INSOLVENČNÍM ŘíZENÍ PRŮMYSLOVÝCH PODNIKU゚
}

\author{
Michaela STERNADELOVÁ \\ Ing., Institute of Economics and Control Systems, Faculty of Mining and Geology, VŠB - Technical \\ University of Ostrava 17. listopadu 15/2172, Ostrava, tel. (+420) 597324392 \\ e-mail: michaela.sternadelova@vsb.cz
}

\begin{abstract}
One of the possible solutions to the debtor's bankruptcy provided by the Insolvency Act is to use the institute of reorganization. According to the Insolvency Act the reorganization is defined as the gradual satisfaction of creditors' claims, while preserving the debtor's business. The permission of reorganization of the debtor's business is subject to the preparation of a reorganization plan describing all measures to be taken, in order to reorganize the debtor's business.

The article deals with the processing and quantification of measures to reorganize the business operations. It analyses the data recorded on found out investment costs, operating costs and revenues, using net present value methods, the profitability index and payback period to assess the proposed project. It assesses, whether the revenues from the proposed investment are sufficient, and ensure adequate satisfaction of the creditors.

Abstrakt

Jako jednu z možností řešení dlužníkova úpadku nabízí insolvenční zákon řešení pomocí institutu reorganizace. Dle insolvenčního zákona je reorganizace definována jako postupné uspokojování pohledávek věřitelů při zachování provozu dlužníkova podniku. Povolení reorganizace dlužníkova podniku je podmíněno zpracováním reorganizačního plánu, ve kterém jsou popsána veškerá opatření, která je nutná provést, aby došlo $\mathrm{k}$ ozdravení provozu dlužníkova podniku.

Článek se zabývá zpracováním a vyčíslením opatření pro ozdravení provozu podniku. Analyzuje data zjištěných nákladů investice, provozních nákladů a tržeb pomocí metod čisté současné hodnoty, indexu rentability a doby úhrady k posouzení navrhovaného projektu. Hodnotí, zda jsou př́imy ze zamýšlené investice, dostatečné a zajistí uspokojení věřitelů.
\end{abstract}

Key words: insolvency, net present value, profitability index

\section{INTRODUCTION}

Entrepreneurship entails not only opportunities of well-deserved profits, but also complications arising from internal and external relations of an enterprise and the overall economic situation of society, where the enterprise operates. These factors may significantly harm such enterprise and cause problems that could seriously threaten its existence. Ways out may vary and involve also handling the situation by insolvency law. It is likely that under the current economic conditions, some companies will not avoid bankruptcy and insolvency proceedings as a way to solve their problems. The issue of dealing with the bankruptcy is an actual and frequent topic of discussions not only of experts.

The operation of industrial enterprises has its specifics, it concerns particularly their assets and capital structure. Industrial enterprises are an integral part of industrial chains. Demand for their products thus often depends on the size of demand for final products (e.g., decrease in housing construction will affect the demand for building materials and many other products) and has a low price elasticity (a reduction in the prices of construction materials does not imply a sharp rise in construction) [1].

The investigated company deals with the processing of recycled rubber. If a creditor submits the proposal for insolvency proceedings against the company by reasons of a long-term default, the court may decide after evaluating the evidences of its bankruptcy. Since the company is interested in continuing its activities, it seeks the permission to resolve the bankruptcy by reorganization. It is therefore necessary to submit at the creditors' meeting a proposal for a new project, which should help the company to repay its liabilities and ensure business operations for the next years. The company wants to push through the plan to produce from used tires, tiles used 
for leisure time. The products will be designed for sports grounds, recreation and reconditioning facilities, playgrounds, gyms, fitness centres, pedestrian zones, terrace facing, balconies and swimming pools. Furthermore, the products will find the use as a floor covering of public spaces with extreme loads in commercial and entertainment centres, recreational areas etc. In order this project was approved, the company will need a calculated project, presenting creditors the company's plans and grounding them by factual calculations.

\section{METHODOLOGY}

For the project evaluation dynamic methods were chosen, considering the time factor. They are suitable mainly for projects, where a longer lifetime is taken into account, which corresponds to this project.

\subsection{Net Present Value}

The dynamic method for the evaluaion of investments was used, which considers as an investment effect the project revenue, which forms the basis of expected profit after tax, depreciation and other possible income. It can be defined as the difference between the discounted revenues generated by the investment project and capital expenditure [4].

$$
N P V=\sum_{n=1}^{N} P n \frac{1}{(1+n)^{n}}-K
$$

$\begin{array}{llll}\text { NPV } & \text { net present value } & \mathrm{N} & \text { lifetime } \\ \mathrm{P} & \text { revenue generated by the investment in each year } & \mathrm{K} & \text { capital expenditure } \\ \mathrm{i} & \text { required rate of return (interest in percentage) } & \\ \mathrm{n} & \text { individual years of lifetime } & \end{array}$

The interpretation of possible results [3]:

NPV $>0$ The discounted revenues exceed the capital expenditure, the investment project is acceptable and ensures the required rate of return.

NPV $<0$ The discounted revenues are less than the capital expenditure, the investment project is unacceptable and does not provide the required rate of return.

$\mathrm{NPV}=0$ The discounted revenues equal the capital expenditure, the investment project is indifferent.

\subsection{Discounted Payback Period}

The period of time for which the project is repaid from the revenues generated by that project. The shorter the payback period, the better the project [4].

\subsection{Profitability Index}

It expresses the ratio of the expected discounted revenues generated by the project to the initial capital expenditures [4].

$P I=\frac{\sum_{m=1}^{\mathbb{N}} P_{n} \frac{1}{\left(1+I^{n}\right)^{n}}}{K}$

The interpretation of possible results:

PI $>1$ The investment project is acceptable

$\mathrm{PI}<1 \quad$ The investment project is unacceptable 


\subsection{Internal Rate of Return}

Such rate of interest, for which the present value of revenues generated by the project equals the capital expenditures. Such rate of interest, for which the net present value is equal to zero [4].

$$
\sum_{n=1}^{N} P n \frac{1}{(1+i)^{n}}=K
$$

$$
\begin{array}{ll}
\mathrm{N} & \text { lifetime } \\
\mathrm{n} & \text { individual years of lifetime } \\
\mathrm{P} & \text { revenues generated by the investment in each year } \\
\mathrm{K} & \text { capital expenditure } \\
\mathrm{i} & \text { searched interest rate coefficient }
\end{array}
$$

The projects providing an interest higher than a required minimum rate of return are considered acceptable. When comparing different versions of projects, it is true that the option, which shows a higher internal rate of return, is preferable [3].

\section{DATA ANALYSIS}

\subsection{Investments}

To implement the proposed project it is necessary to perform construction works at the company's premises. Further, it is necessary to purchase the machinery to manufacture rubber tiles. For the investment costs, see Table 1 Investment costs.

Tab.1 Investment costs

\begin{tabular}{|c|r|}
\hline Investment & \multicolumn{1}{c|}{ Price } \\
\hline Machinery Investment: & CZK 4,806,400 \\
\hline Press & $C Z K 2,246,400$ \\
\hline Set of moulds & $C Z K$ 700,000 \\
\hline Handling equipment & $C Z K$ 600,000 \\
\hline Mixer & $C Z K$ 900,000 \\
\hline Assembly + Transport & $C Z K 260,000$ \\
\hline$\Delta$ NWC & $C Z K$ 100,000 \\
\hline Construction Investment & CZK 1,692,800 \\
\hline \hline Total Investments & CZK 6,499,200 \\
\hline
\end{tabular}

Source: inherent processing

\subsection{Revenues}

The company decided to produce two types of products - red and black tiles. It is assumed that the company will produce these products, considering the demand, in different quantities. The proportion of black tiles of the production will be $40 \%$ and the proportion of colour tiles will be $60 \%$ of the total production volume. The given machinery provides the production of $200 \mathrm{~kg}$ of products per hour. The company assumes 253 working days a year. For two-shift operations (16 hrs/day) the running time will be 4,048 hours per year. In addition, the company expects an increase in production by $10 \%$ during the first three years, see Tab. 2 Amount of products - plan. 
Tab. 2 Amount of products - plan

\begin{tabular}{|l|llll|}
\hline & $\mathbf{2 0 1 0}$ & $\mathbf{2 0 1 1}$ & $\mathbf{2 0 1 2}$ & $\mathbf{2 0 1 3}$ \\
\hline Number of working days per year & 253 & 253 & 253 & 253 \\
$\begin{array}{l}\text { Number of working hours (days * } \\
\text { 16) }\end{array}$ & 4048 & 4048 & 4048 & 4048 \\
Machine capacity (t/hour) & 0.25 & & & 0.33275 \\
Product quantity (t/year) & 1,012 & 1,132 & $1,224.5$ & 1,347 \\
\hline \multicolumn{1}{|c|}{ Thereof: } & & & 489.8 & 538.8 \\
\hline Black tiles (40\% of production) & 404.8 & 445.3 & 734.7 & 808.2 \\
Colour tiles (60 \% of production) & 607.2 & 667.9 & & $\mathbf{1 3 4 7}$ \\
\hline \hline
\end{tabular}

Source: inherent processing

The expected product price is CZK 28,000 per ton of black tiles and CZK 42,000 per ton of coloured tiles. For the assumed revenues see Tab. 3 Revenues - Plan

Tab. 3 Revenues - Plan

\begin{tabular}{|l|l|l|l|l|}
\hline Product & $\mathbf{2 0 1 0}$ & $\mathbf{2 0 1 1}$ & $\mathbf{2 0 1 2}$ & $\mathbf{2 0 1 3}$ \\
\hline \multirow{3}{*}{ Black tiles } & CZK 11,334,400 & CZK 12,467,840 & CZK 13,714,624 & CZK 15,086,086 \\
Colour tiles & CZK 25,502,400 & CZK 28,052,640 & CZK 30,857,904 & CZK 33,943,694 \\
\hline \hline & & & & \\
Total & CZK 36,836,800 & CZK 40,520,480 & CZK 44,572,528 & CZK 49,029,780 \\
\hline
\end{tabular}

Source: inherent processing

\subsection{Costs}

\section{Depreciation}

For the investment depreciation the straight-line method of depreciation has been chosen. The machinery investment was placed into the second depreciation group and the construction investment into the fifth depreciation group, see Tab. 4 Depreciation schedule. The calculation of depreciation is made according to the formula (input price * rate of the appropriate year)/100 [6]. The depreciation is shown in Tab. 5 Depreciation of machinery and construction investments.

Tab. 4 Depreciation schedule

\begin{tabular}{|l|r|r|}
\hline \multicolumn{1}{|c|}{ Depreciation } & Machinery & Construction Investment \\
\hline input price & CZK 4,806,400 & CZK 1,692,800 \\
depreciation group & 2 & 5 \\
depreciating method & straight-line depreciation & straight-line depreciation \\
rate in the 1st year & 11 & 1.4 \\
rate in the 2nd year & 22.25 & 3.4 \\
\hline
\end{tabular}

Source: inherent processing 
Tab. 5 Depreciation of machinery and construction investments

\begin{tabular}{|l|r|l|l|}
\hline \multicolumn{2}{|c|}{ Construction investment } & \multicolumn{2}{c|}{ Machinery } \\
\hline Depreciation & Amount & Depreciation & Amount \\
\hline 1st year & CZK 23,699 & 1st year & CZK 528,704 \\
2nd - 30th years & CZK 57,555 & 2nd - 5th years & CZK 1,069,424 \\
\hline \hline Total & CZK 1,692,800 & Total & CZK 4,806,400 \\
\hline
\end{tabular}

Source: inherent processing

\section{Labour costs}

Wages of workers are calculated in Tab. 6 Labour costs. For the production the two-shift operation is taken into account, in the first year five manual workers will work in one shift, each year the number of the workers will increase by one per each shift. With regard to an interim increase in production by $10 \%$ also the employees' wages will increase by $10 \%$.

Tab. 6 Labour costs (own calculation)

\begin{tabular}{|c|c|c|c|c|c|c|c|c|c|c|}
\hline & \multicolumn{5}{|c|}{2010} & \multicolumn{5}{|c|}{2011} \\
\hline jobs & $\begin{array}{l}\begin{array}{l}\text { number of } \\
\text { workers }\end{array} \\
\end{array}$ & $\begin{array}{l}\text { monthly } \\
\text { wage of a } \\
\text { worker }\end{array}$ & $\begin{array}{l}\text { costs per } \\
\text { employee } \\
(1.34)\end{array}$ & $\begin{array}{l}\text { number } \\
\text { of } \\
\text { months }\end{array}$ & $\begin{array}{l}\text { annual wage of a } \\
\text { worker }\end{array}$ & $\begin{array}{l}\text { number of } \\
\text { workers }\end{array}$ & $\begin{array}{l}\text { monthly } \\
\text { wage of a } \\
\text { worker }\end{array}$ & $\begin{array}{l}\text { costs per } \\
\text { employee } \\
(1.34)\end{array}$ & $\begin{array}{l}\text { number } \\
\text { of } \\
\text { months }\end{array}$ & $\begin{array}{l}\text { annual wage of a } \\
\text { worker }\end{array}$ \\
\hline Technologist & 1 & 28,000 & 37,520 & 12 & CZK 450,240 & 1 & 30,800 & 41,272 & 12 & CZK 495,264 \\
\hline $\begin{array}{l}\text { Sales and } \\
\text { Marketing }\end{array}$ & 2 & 23,000 & 30,820 & 12 & CZK 739,680 & 2 & 25,300 & 33,902 & 12 & CZK 813,648 \\
\hline Procurement & 1 & 23,000 & 30,820 & 12 & CZK 369,840 & 1 & 25,300 & 33,902 & 12 & CZK 406,824 \\
\hline Accounting & 1 & 23,000 & 30,820 & 12 & CZK 369,840 & 1 & 25,300 & 33,902 & 12 & CZK 406,824 \\
\hline $\begin{array}{l}\text { Administrative } \\
\text { employee }\end{array}$ & & & & & $C Z K 1,929,600$ & & & & & $C Z K 2,122,560$ \\
\hline $\begin{array}{l}\text { Production } \\
\text { line }-2 \text { shifts }\end{array}$ & 10 & 18,000 & 24,120 & 12 & CZK 2,894,400 & 12 & 19,800 & 26,532 & 12 & CZK 3,820,608 \\
\hline Shipment & 2 & 18,000 & 24,120 & 12 & CZK 578,880 & 3 & 19,800 & 26,532 & 12 & CZK 955,152 \\
\hline Charwoman & 1 & 10,000 & 13,400 & 12 & CZK 160,800 & 1 & 11,000 & 14,740 & 12 & CZK 176,880 \\
\hline Maintenance & 1 & 12,000 & 16,080 & 12 & CZK 192,960 & 1 & 13,200 & 17,688 & 12 & CZK 212,256 \\
\hline $\begin{array}{l}\text { Manual } \\
\text { workers }\end{array}$ & & & & & $C Z K 3,827,040$ & & & & & CZK 5,164,896 \\
\hline $\begin{array}{l}\text { Annual } \\
\text { payroll }\end{array}$ & & & & & CZK 5,756,640 & & & & & CZK 7,287,456 \\
\hline & & & 2012 & & & & & 2013 & & \\
\hline jobs & $\begin{array}{l}\text { number of } \\
\text { workers }\end{array}$ & $\begin{array}{l}\text { monthly } \\
\text { wage of a } \\
\text { worker }\end{array}$ & $\begin{array}{l}\text { costs per } \\
\text { employee } \\
(1.34)\end{array}$ & $\begin{array}{l}\text { number of } \\
\text { months }\end{array}$ & $\begin{array}{l}\text { annual wage } \\
\text { of a worker }\end{array}$ & $\begin{array}{l}\text { number of } \\
\text { workers }\end{array}$ & $\begin{array}{l}\text { monthly } \\
\text { wage of a } \\
\text { worker }\end{array}$ & $\begin{array}{l}\text { costs per } \\
\text { employee } \\
(1.34)\end{array}$ & $\begin{array}{l}\text { number } \\
\text { of } \\
\text { months }\end{array}$ & $\begin{array}{l}\text { annual wage of } \\
\text { a worker }\end{array}$ \\
\hline Technologist & 1 & 33,880 & $45,399.2$ & 12 & CZK 544,790 & 1 & 37,268 & $49,939.12$ & 12 & CZK 599,269 \\
\hline $\begin{array}{l}\text { Sales and } \\
\text { Marketing }\end{array}$ & 2 & 27,830 & $37,292.2$ & 12 & CZK 895,013 & 2 & 30,613 & $41,021.42$ & 12 & CZK 984,514 \\
\hline Procurement & 1 & 27,830 & $37,292.2$ & 12 & $2 \quad$ CZK 447,506 & 1 & 30,613 & $41,021.42$ & 12 & CZK 492,257 \\
\hline Accounting & 1 & 27,830 & $37,292.2$ & 12 & $2 \quad$ CZK 447,506 & 1 & 30,613 & $41,021.42$ & 12 & CZK 492,257 \\
\hline $\begin{array}{l}\text { Administrative } \\
\text { employee }\end{array}$ & & 0 & & & $\begin{array}{r}C Z K \\
2,334,816 \\
\end{array}$ & & & & & $C Z K 2,568,298$ \\
\hline $\begin{array}{l}\text { Production } \\
\text { line }-2 \text { shifts }\end{array}$ & 14 & 21,780 & $29,185.2$ & 12 & $\begin{array}{r}\text { CZK } \\
4,903,114 \\
\end{array}$ & 16 & 23,958 & $32,103.72$ & 12 & CZK 6,163,914 \\
\hline Shipment & 3 & 21,780 & $29,185.2$ & 12 & $\begin{array}{r}\text { CZK } \\
1,050,667 \\
\end{array}$ & 3 & 23,958 & $32,103.72$ & 12 & CZK $1,155,734$ \\
\hline Charwoman & 1 & 12,100 & 16,214 & 12 & $2 \quad$ CZK 194,568 & 1 & 13,310 & $17,835.4$ & 12 & CZK 214,025 \\
\hline Maintenance & 1 & 14,520 & $19,456.8$ & 12 & $2 \quad$ CZK 233,482 & 1 & 15,972 & $21,402.48$ & 12 & CZK 256,830 \\
\hline $\begin{array}{l}\text { Manual } \\
\text { workers }\end{array}$ & & & & & $\begin{array}{r}C Z K \\
6,381,830 \\
\end{array}$ & & & & & $C Z K 7,790,503$ \\
\hline $\begin{array}{l}\text { Annual } \\
\text { payroll }\end{array}$ & & & & & $\begin{array}{r}\text { CZK } \\
8,716,646 \\
\end{array}$ & & & & & $\begin{array}{r}\text { CZK } \\
10,358,800 \\
\end{array}$ \\
\hline
\end{tabular}

Source: inherent processing 


\section{Transport Costs}

For the transportation of materials and products a sum of CZK 1,000,000 was defined for the first year, which will also increase annually by $10 \%$.

\section{Production Costs}

To manufacture the finished product it is necessary to buy a granulated material, of which the product will be made. The production of a ton of finished product requires 0.94 tons of granulate (the granulate price is $5,000 \mathrm{CZK} / \mathrm{t}$ ). The granulate must be mixed in production with a binder (price $40,000 \mathrm{CZK} / \mathrm{t}$ ) in the quantity of 0.06 tons per ton of products. The production of coloured tiles requires a dye in the quantity of 0.01 tons per ton of products (price 40,000 CZK/t)

Further, the energy costs were calculated. The need for electricity was determined to be $650 \mathrm{~kW}$ per hour of operating time at a price of CZK 4.50 per $\mathrm{kW}$. The need for water was set to $1 \mathrm{~m}^{3}$ per hour of operating time at a price of $44.50 \mathrm{CZK} / \mathrm{m}^{3}$. Other costs of production are shown in Tab. 7 Total costs.

Tab. 7 Total costs

\begin{tabular}{|c|c|c|c|c|}
\hline & 2010 & 2011 & 2012 & 2013 \\
\hline 1 Transport costs & CZK $1,000,000$ & CZK 1,100,000 & CZK $1,210,000$ & CZK $1,331,000$ \\
\hline 2 Production costs & CZK 28,522,632 & CZK 32,346,047 & CZK 36,284,097 & CZK 40,683,996 \\
\hline purchase of granulate & CZK 4,756,400 & CZK 5,232,040 & CZK 5,755,244 & CZK 6,330,768 \\
\hline binder for products & CZK 2,428,800 & CZK 2,671,680 & CZK 2,938,848 & CZK 3,232,733 \\
\hline dye for products & CZK 4,857,600 & CZK 5,343,360 & CZK 5,877,696 & CZK 6,465,466 \\
\hline wages of workers & CZK 3,827,040 & CZK 5,164,896 & CZK 6,381,830 & CZK 7,790,503 \\
\hline electrical energy & CZK $11,840,400$ & CZK 13,024,440 & CZK 14,326,884 & CZK 15,759,572 \\
\hline water & CZK 180,136 & CZK 198,150 & CZK 217,965 & CZK 239,761 \\
\hline repairs of $4 \%$ of PC technology & CZK 192,256 & CZK 211,482 & CZK 232,630 & CZK 255,893 \\
\hline protectives $(10,000$ CZK/employee $)$ & CZK 140,000 & CZK 170,000 & CZK 190,000 & CZK 210,000 \\
\hline assets & CZK 100,000 & CZK 110,000 & CZK 121,000 & CZK 133,100 \\
\hline advertising costs & CZK 100,000 & CZK 110,000 & CZK 121,000 & CZK 133,100 \\
\hline minor services & CZK 100,000 & CZK 110,000 & CZK 121,000 & CZK 133,100 \\
\hline 3 Fixed production costs & CZK 3,052,456 & CZK 3,896,460 & CZK 4,187,477 & CZK 4,508,957 \\
\hline manufacturing overhead & CZK 570,453 & CZK 646,921 & CZK 725,682 & CZK 813,680 \\
\hline $\begin{array}{l}\text { administrattve expenses (wages of } \\
\text { administrative workers) }\end{array}$ & CZK 1,929,600 & CZK 2,122,560 & CZK 2,334,816 & CZK 2,568,298 \\
\hline depreciation & CZK 552,403 & CZK 1,126,979 & CZK 1,126,979 & CZK 1,126,979 \\
\hline Total Costs & CZK 32,575,088 & CZK 37,342,507 & $C Z K 41,681,574$ & CZK 46,523,952 \\
\hline
\end{tabular}

Source: inherent processing

\section{Fixed Production Costs}

The administrative overhead expenses consist of the wages of administrative workers and the manufacturing overhead was set to $2 \%$ of the production costs, see Tab. 7 Total costs.

\subsection{Investment Evaluation}

In 2010 , the corporate income tax rate was $20 \%$, but there is a presumption that the rate will increase. Therefore, with regard to the further development the expected rate was increased to $22 \%$. The interest rate 
(required rate of return) of $12 \%$ was chosen for the entire evaluated period. The above data were summarized in Tab. 8 Input data.

Tab. 8 Input data

\begin{tabular}{|l|r|r|r|r|r|}
\hline Year: & \multicolumn{1}{|c|}{0} & \multicolumn{1}{c|}{2010} & \multicolumn{1}{c|}{2011} & \multicolumn{1}{c|}{2012} & \multicolumn{1}{c|}{2013} \\
\hline Capital contribution & $6,499,200$ & & & & \\
\hline Revenues & & $36,836,800$ & $40,520,480$ & $44,572,528$ & $49,029,780.8$ \\
\hline - depreciation & & $552,403.2$ & $1,126,979.2$ & $1,126,979.2$ & $1,126,979.2$ \\
\hline - other costs & & $32,575,087.84$ & $37,342,507.34$ & $41,681,573.85$ & $46,523,952.39$ \\
\hline $\begin{array}{l}\text { Tax rate (estimate for the entire } \\
\text { evaluated period) }\end{array}$ & $22.00 \%$ & & & & \\
\hline $\begin{array}{l}\text { Interest rate (estimate for the entire } \\
\text { evaluated period) }\end{array}$ & 12 & & & & \\
\hline
\end{tabular}

Source: inherent processing

Based on the above data the calculation has been performed, see Tab. 9 Calculation.

TTab. 9 Calculation

\begin{tabular}{|c|c|c|c|c|c|c|}
\hline & Year: & $\boldsymbol{0}$ & 1 & 2 & 3 & 4 \\
\hline 1 & Capital contribution & $-6,499,200$ & & & & \\
\hline 2 & Revenues & & $36,836,800$ & $40,520,480$ & $44,572,528$ & $49,029,780.8$ \\
\hline 3 & - depreciation & & $552,403.2$ & $1,126,979.2$ & $1,126,979.2$ & $1,126,979.2$ \\
\hline 4 & - other costs & & $32,575,087.84$ & $37,342,507.34$ & $41,681,573.85$ & $46,523,952.39$ \\
\hline 5 & $\begin{array}{l}\text { Gross profit (profit before tax) (line } \\
2 \text { - line } 3 \text { - line } 4 \text { ) }\end{array}$ & & $3,709,308.96$ & $2,050,993.456$ & $1,763,974.946$ & $1,378,849.215$ \\
\hline 6 & - Tax (line $5 *$ tax rate) & & $816,047.97$ & $451,218.56$ & $388,074.49$ & $303,346.83$ \\
\hline 7 & $\begin{array}{l}\text { Net profit (profit after tax) (line } 5 \text { - } \\
\text { line } 6 \text { ) }\end{array}$ & & $2,893,260.99$ & $1.599,774.90$ & $1,375,900.46$ & $1,075,502.39$ \\
\hline 8 & + Depreciation (line 3) & & $552,403.2$ & $1,126,979.2$ & $1,126,979.2$ & $1,126,979.2$ \\
\hline 9 & Cash flow (line $7+$ line 8 ) & & $3,445,664.19$ & $2,726,754.10$ & $2,502,879.66$ & $2,202,481.59$ \\
\hline 10 & Interest rate in $\%$ & & 12 & 12 & 12 & 12 \\
\hline 11 & $\begin{array}{l}\text { Discount rate }(1 /((1+\text { interest } \\
\text { rate/100) raised to a power of current year) }\end{array}$ & & 0.8929 & 0.7972 & 0.7118 & 0.629 \\
\hline 12 & $\begin{array}{l}\text { Present value (discounted cash } \\
\text { flow) (line } 9 * \text { line } 11)\end{array}$ & & $3,076,485.88$ & $2,173,751.67$ & $1,781,500.30$ & $1,399,716.87$ \\
\hline 13 & $\begin{array}{l}\text { Net Present Value (ČSH, or NPV) } \\
\text { (line } 1+\text { line 12) }\end{array}$ & & $-3,422,714.12$ & $-1,248,962.45$ & $\mathbf{5 3 2 , 5 3 7 . 8 6}$ & $1,932,254.72$ \\
\hline & Profitability Index (PI) $(\Sigma 1.12 /-1.1)$ & $8,431,454.72$ & l & $6,499,200$ & $=$ & 1.30 \\
\hline
\end{tabular}

Source: inherent processing

As it is evident from the calculation, the net present value of the investment is a positive value (assuming a payback period of 3 years), thus according to the theoretical bases it is possible to accept the proposed project. approved.

The profitability index is greater than one, therefore according to this criterion the project can be

Under the given parameters, the payback period of the project should be 2-3 years, the project will earn in the third year over half a million crowns, and in the fourth year nearly two million. 
The internal rate of return of the project was calculated to $26.74 \%$. The calculation was performed using the function "rate of return" in MS Excel. It is thus higher than the required rate of return. So it would be possible to accept he project according to this criterion, too.

\section{CONCLUSION}

According to all the investment assessment criteria, the proposed project could be accepted. However, it should be noted that the evaluation works with certain assumptions, which in reality need not necessarily occur. It concerns in particular the assumption of the volume of sales. The project assumes that all the production will be sold for fixed prices. Such ideal conditions do not occur at any time. It is necessary to take into account the market situation of particular product, product demand and market position of the product (whether it is new, luxury goods, goods subject to fluctuations in demand, and whether it is a classic product that customers will always buy). The major disadvantage of this concrete type of product (rubber tiles for leisure time) is its price, although it corresponds to the product quality, and the fact that the rubber tiles belong rather to top-quality products. It is therefore possible that customers take advantage of cheaper alternatives.

Furthermore, the creditors themselves must approve, whether such rate of return of the project will be enough to cover their outstandings.

\section{ACKNOWLEDGEMENT}

The paper was prepared with the financial support of the project of the Ministry of Education, Youth and Sports SP/201057 "Economic aspects of insolvency proceedings under conditions of an industrial enterprise."

\section{REFERENCES}

[1] MACHKOVÁ, H. Mezinárodní marketing. [International Marketing.] 3rd actual. and rev. ed. Prague: Grada Publishing, 2009, p. 196, ISBN 978-80-247-2986-2.

[2] SYNEK, M. et al. Podniková ekonomika. [Business Economics.] 4th rev. and suppl. ed. Prague: C. H. Beck, 2007, p. 473, ISBN 80-7179-892-4.

[3] VALACH, J. et al. Finanční řizení podniku. [Enterprise Financial Management.] 1st ed. Prague: Ekopress, 1997, p. 247, ISBN 80-901991-6-X.

[4] VALACH, J. Investiční rozhodování a dlouhodobé financování. [Investment Decision-Making and LongTterm Financing.] 2nd rev. ed. Prague: Ekopress, 2005, p. 465, ISBN 80-86929-01-9.

[5] Act No. 182/2006 Coll., on Bankruptcy and Its Resolution (Insolvency Act), as amended.

[6] Act No. 586/1992 Coll., on Income Tax, as amended. 